\title{
The discovery of the possible reasons for delayed graduation and dropout in the light of a qualitative research study*
}

\author{
VERONIKA BOCSI, TÍMEA CEGLÉDI, ZSÓFIA KOCSIS, KAROLINA ESZTER KOVÁCS, KLÁRA KOVÁCS, ANETTA MÜLLER, \\ KATALIN PALLAY, BARBARA ÉVA SZABÓ, FRUZSINA SZIGETI** and DORINA ANNA TÓTH
}

Doctoral Program on Educational and Cultural Sciences, University of Debrecen, Debrecen, Hungary

(Received: July 26, 2018; accepted: November 13, 2018)

\begin{abstract}
Higher educational dropout is a significant area of education policy in Hungary. First, the proportion of graduated higher educational students is low when compared to the OECD average, which may be caused by dropout from higher educational courses. On the other hand, although the phenomenon of dropout has been closely investigated in several international research papers, the methodology used to determine the dropout ratio is unsatisfactory, mainly due to the lack of expert consensus. As a consequence, we do not have precise data regarding the dropout ratios, which make investigations related to this area even more necessary. The aim of this study was to measure the possible reasons for delayed graduation and dropout, and it was carried out as a qualitative study based on existing theories. In our investigation, the role of the sociocultural background; the years prior to the time spent in higher education; and the motivation of the choice of institution, employment, sports, and social activities were measured through an analysis of seven individual interviews and one focus group conversation involving 10 participants based on a semi-structured interview methodology. The causes of delayed graduation and dropout, which are more difficult to observe, are an inappropriately chosen institution and/or course, employment while studying intensively in a higher education institution, competitive sport and friends with a negative attitude toward learning. Our analysis provides a stable basis for a wider questionnaire-based investigation on a representative sample and its main units have been developed according to the research blocks of the interview analysis.
\end{abstract}

Keywords: delayed graduation; dropout; higher education

\section{INTRODUCTION}

Graduation and achieving a higher educational degree are the result of successfully completing tertiary education. It is a type of human capital investment, which is intended to increase the individual's ability to be productive and to earn a higher income (Becker, 1975; Varga, 1998, 2015). Compared to the trends in Organisation for Economic Cooperation and Development (OECD) countries, the ratio of students who get their first degree in tertiary education is lower in Hungary, especially regarding PhD studies (OECD, 2015), which may be caused by the failure to meet the degree requirements and by student dropout.

Regarding higher educational students' dropout ratio, no precise data are available, and the methodology determining the ratio of dropout is unsatisfactory, mainly because of the lack of an expert consensus (Fenyves et al., 2017; Lukács \& Sebö, 2015). The Eurostat summary (2016) states that, in Latvia, $57.6 \%$ of those between 30 and 34 years old have completed their higher educational studies. This ratio is $54.6 \%$ in Cyprus, 52.3\% in Ireland and Luxembourg, and $50.2 \%$ in Sweden. The lowest ratio of graduation is found in Italy (25.3\%), Romania (25.6\%), Malta (27.8\%), and Slovakia $(28.4 \%)$. The ratio in Hungary $(35.0 \%)$ is lower than the mean for the EU (39.0\%), although it is above
$30.0 \%$ determined by the Action Programme of the EU to be achieved by 2020 (Eurostat, 2016).

The aim of this study is to investigate pedagogy students who have already dropped out, despite the fact that this educational field can be associated with a lower dropout ratio. Who are the students, who stagnate in the educational system, have a lower level of educational progress or drop out, and thus quit their studies without graduating (Fenyves et al., 2017; Lukács \& Sebö, 2015)? What are the factors sociocultural background, family, friends, school career, employment studying, and leisure-time activities (sports and entertainment) - that can predict institutional dropout? To answer these questions, a qualitative research methodology was applied through the analysis of seven individual interviews and one focus group conversation involving 10 participants, based on a semi-structured interview methodology. The interviewees were selected with non-probability

*Project no. 123847 has been implemented with the support provided from the National Research, Development and Innovation Fund of Hungary, financed under the $\mathrm{K} \_17$ funding scheme. ** Correspondence: Fruzsina Szigeti, Faculty of Arts, Institute of Educational Studies and Cultural Management, University of Debrecen, 1 Egyetem Square, 4032 Debrecen, Hungary; Phone: +3606209675 600; e-mail: szigeti.fruzsina.89@gmail.com

This is an open-access article distributed under the terms of the Creative Commons Attribution 4.0 International License, which permits unrestricted use, distribution, and reproduction in any medium, provided the original author and source are credited, a link to the CC License is provided, and changes - if any - are indicated. (SID_1) 
distribution, expert, and snowball methods. On the basis of the interviews conducted during the research, no far-reaching conclusions can be claimed because of the less number of the participants, but we can attempt to distinguish the main traits.

\section{LITERATURE}

Higher educational dropout became the focus of research in the 1960s and it was embodied in a theoretical form by the interactionist model of Tinto in the 1970s. In the 1970s, analyses have been published that investigate the phenomenon of dropout through analyzing the higher education statistics of the different countries. For instance, Fulton (1977) examined the statistics of the United Kingdom, whereas de Corrado and Trivellato (1977) reviewed the Italian statistics from the beginning of the expansion. Since then, several models have been elaborated (e.g., Astin, 1993; Bennett, 2003), which have drawn attention to different factors, although some factors have appeared repeatedly.

It is necessary to draw attention to an individual's psychological characteristics, such as personality, motivation (both internal and external), personal development, health status, and health-awareness as influential factors (Braxton, Shaw-Sullivan, \& Johnson, 1997; Southerland, 2006). Another important point is the sociological-social aspect, which highlights the characteristics of the student's environment, the role of classmates and educators, and the characteristics, and the prestige of higher education, etc. (e.g., Braxton et al., 1997; Southerland, 2006). Other theories emphasize the role of economical-organizational factors, including costeffectiveness (at both institutional and individual levels) and the characteristics of the institutions (resources, services, and structure; Cabrera, Nora, \& Castaneda, 1993; Southerland, 2006). Besides these, pedagogical-psychological factors play an important role in investigations into the reasons for dropout from a comprehensive perspective; these factors include both pedagogical and psychological aspects, highlighting the importance of the learning style and attitudes, or the teaching staff (Cabrera et al., 1993).
The iceberg model (OECD, 2012) includes six factors, which play a significant role in stagnation in the higher education system and in the dropout ratio (Fig. 1).

1. Educational performance: this is the best indicator of dropout, as low-academic achievement can restrain students in their higher educational development. Academic achievement is a visible part of the iceberg and it is easy to identify as a background factor in the move toward school dropout.

2. Students' behavior: this includes the students' values, and monitors whether education and learning play an important role in individuals' value systems. Furthermore, this also includes deviant behavior elements and health-damaging behavior.

3. The background of students and their families: the family has a significant impact on the achievement of the student, and the lack of support often leads to dropout.

4. School structures, resources, and practices: the method of teaching-learning, the practice of the institution's educators, relations with peers, and curricular and extracurricular activities also influence students' motivation, which can decrease the level of dropout.

5. Educational system level policies: education policy can also decrease the level of dropout by yearly tracking or concrete interventions (decreasing school violence, creating and maintaining an appropriate institution system, etc.)

6. Labor market conditions: changes in the labor market (attractive but easily filled seasonal labor markets, e.g., tourism) can have an impact on dropout. To achieve financial independence and to improve their economic situation, students may leave school prematurely without completing their studies.

In the literature, several examples can be found for the categorization of the different factors increasing the likelihood of the dropout. By the middle of the 70s, academic withdrawal and non-academic withdrawal progresses are differentiated (e.g., Fulton, 1977). Otherwise, the groups of students who dropped out are distinguished according to the

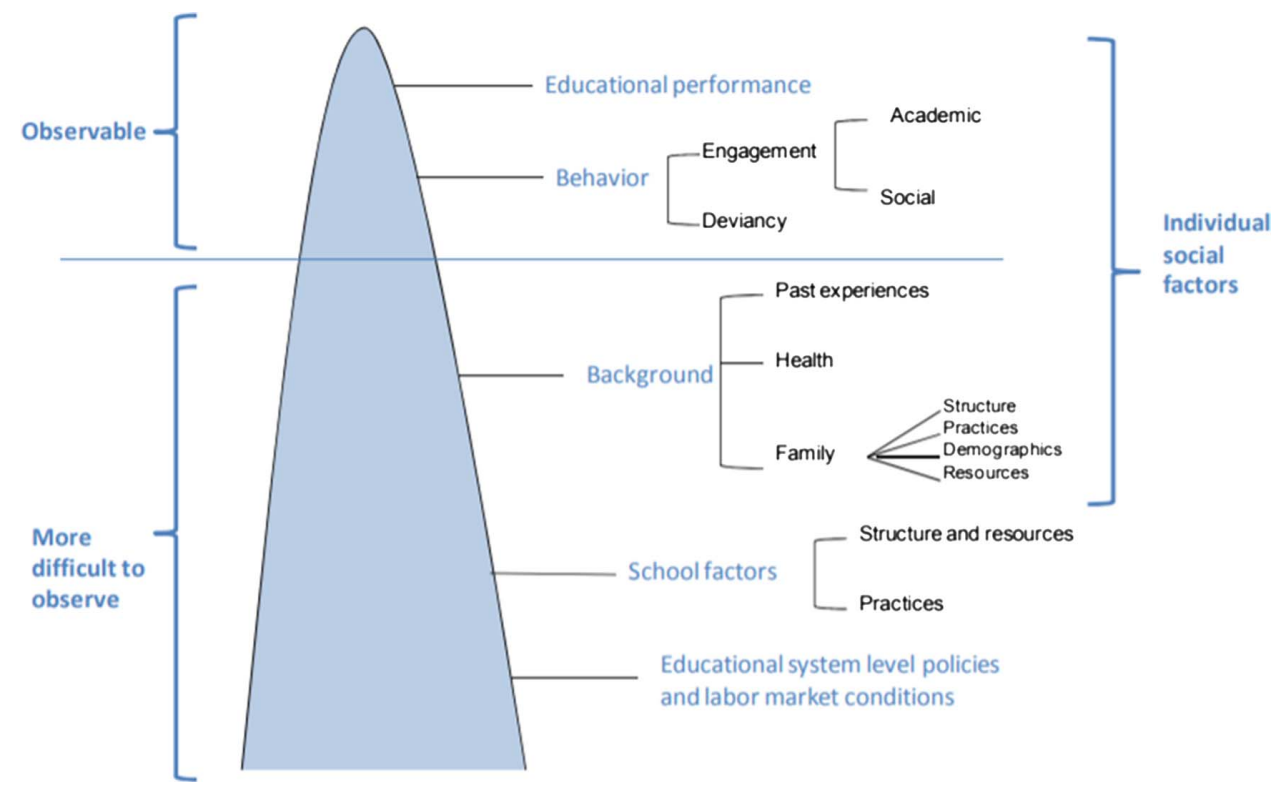

Fig. 1. The iceberg model of dropout. Source: OECD (2012, p. 21) (https://www.oecd.org/education/school/50293148.pdf) 
compulsory or conscious nature of the decision. On the basis of the final decision, the literature separates permanent or interval dropout progress.

\section{The sociocultural background}

The socioeconomic status (SES) of parents is one of the most important and most frequently investigated factors. Higher SES usually correlates with lower dropout rates (Alivernini \& Lucidi, 2011). Besides SES, parental involvement and support are significant as well, and these are obviously protective factors with regard to school dropout (Jimerson, Egeland, Sroufe, \& Carlson, 2000; Parr \& Bonitz, 2015). According to retrospective research, poverty is one of the most important predictors of quitting the educational system (De Witte, Cabus, Thyssen, Groot, \& van den Brink, 2013). This is mainly notable among those who experienced extreme poverty in their childhood or lived in extreme poverty during that period. Other factors are a lack or low level of engagement in school, which also increase the chances of quitting education (at all levels) (Robinson, Jaggers, Rhodes, Blackmon, \& Church, 2017). The quality and strength of the parent-child relationship is the most relevant issues at this level (Jimerson et al., 2000).

Dropout is also influenced by other demographical factors, such as gender. According to UNESCO statistics (2012), the rate of the dropout is significantly higher among girls. This can be caused by economic factors (e.g., the costs of education), by the household (e.g., the involvement of females in household chores), by the school (e.g., extracurricular activities and a lack of gender equality at school), and by the culture (e.g., early marriage, pregnancy, and parenthood; Shahidul \& Zehadul Karim, 2015).

Gender is not only related to the frequency of the dropout but also to its type. According to Fulton (1977), non-academic dropout is more common among females. It is important to note that males' dropout rates are higher at certain times and in certain types of higher educational systems (Lukács \& Sebö, 2015; Tinto, 1975), thus, the current higher ratio of females cannot be considered everywhere and always as a valid trend.

Adaptation, including the social and academic integration of young people, has a huge relevance regarding the environment. This includes both intragenerational (peers) and intergenerational (educators) integration, and both have a huge influence on academic achievement (Pusztai, 2004) and on health awareness (sport and healthy lifestyle; Kovács, Kovács, \& Nagy, 2016). However, it is important to draw greater attention to the individual, as it is the individuals who - in the end - create their own lives, and this mostly occurs at this level. The importance of the family is still visible but individuals make their own decisions about their lives and they have to be taken into consideration. For this reason, intrapersonal characteristics make a more marked appearance in each stage of life, and consequently, in dropping out from education, as well.

\section{The years before higher education}

According to Veres (2017), promoting gender equality and the prevention of the dropout of disadvantaged students is one important challenge faced by the Hungarian education system. It is important to be able to measure students' social environment and to examine and determine the risk factors. It is also relevant to understand individuals' specific expectations before entering higher education when examining the dropout factors. It is obviously important to understand their educational career, their learning habits, and the factors that hinder their entrance into higher education and anything that could contribute to the factors leading to dropout.

Teichler (1998) states that dropout appearing in learning paths can be caused by strategic decisions, emergencies, or even conscious decisions. Fehérvári (2012) measured learning paths in vocational education, and she highlighted the failures in learning at primary and secondary levels, as well, and also stated on the basis of several studies (Bánkúti, Horváth, \& Lukács, 2004; Liskó, 2003) that the reasons for dropout at the secondary level can be traced back to primary education. Moreover, failures continue at the secondary level as well and can also have an impact on the tertiary level.

Besides the support of parents, self-development, motivation, and appropriate learning strategies can be significant, and it is also important to mention academic achievement and vocational guidance. Several aspects need to be taken into consideration during the assessment of an institution as these can also determine the quality of the school work (Gyökös, 2015). According to Gyökös (2015), school leadership, human resource management, school policies and strategies, and organizational processes and resources can be included here, as can the satisfaction of employees, parents, and students. Edmonds (1979) determines five factors regarding effective schools, which are appropriate professional leadership, an organized and safe environment, the importance of the development of fundamental skills, the high level of expectations regarding students' knowledge, and the frequent evaluation of students' learning progress. Measuring the indices of academic achievement, Szemerszki (2015) determined the aggregated results of the semester, the grades for the featured subjects, results of academic and art competitions, and the language exam as the most important indices. Secondary school failure, for example, failing a subject, is mentioned here as a negative phenomenon. Later on, she created an academic achievement index on the basis of these factors.

\section{The motivation of the choice of the higher education institution}

The choice of the institution has a huge influence on students' lives, as it is likely to determine whether the students will live at home, what kind of livelihood opportunities they will have, whether it will be necessary to take out a loan, and whether they will maintain contact with their primary and secondary school friends (Galotti \& Mark, 1994). The choice of institution and course is related to values and is the result of a rational decision (after secondary education), which prioritizes the financial costs incurred by higher educational studies. After the recent expansion of higher education, the motivation regarding the choice of institution and the research related to it has changed, as nowadays the location and duration of the course has become the focus of the research (Pusztai, 2015b). 
According to the investigation of Csuka and Banász (2014), students' (individual) factors, such as their social and economic status, the parents' educational level, higher educational costs and scholarships, and the career advice given by close relatives all have a significant effect. Furthermore, institutional factors, such as the location, type, condition and ranking of the higher educational institution, and the quality of the teaching, as well as the prestige, equipment and infrastructure of the institution, play an important role as well.

Investigating career decisions, Kovács, Müller, Fenyves, Szücs, and Bácsné (2017) created a hierarchic threecomponent model in which negative components dominated. The inability to make a decision is the first level of the model and is mainly caused by demotivation and dysfunctional behavior related to decision-making. The second and third factors are the lack of information and the inconsistent use of information. The former is caused by the lack of open days and recruitment activity and the latter by the unreliability of information, its contradictions, problems arising when making compromises, and internal and external conflicts.

One of the reasons for the dropout can also be that the students realize that the institution or the department does not provide what they expected only after starting their training. This can be caused by the lack of information previously acquired about higher education, or the inadequate choice of the institution or the department that does not fit the students' work values or professional concept (Knafo \& Sagiv, 2004). At the same time, the concepts of work and occupation are not final at this age (emerging adulthood) yet. The socialization progress in the higher educational institutions can reinforce students' professional concepts; however, the negative experiences and the lack of integration can lead to deliberate, voluntary dropout.

\section{Employment}

The characteristics of the labor market provide one of the most important external contexts behind the dropout. However, its mode of action may be different. In the research of Bennett (2003), the attraction of the high-income professions can be detected as a pull-effect that uproots young people from higher education, functioning as a sort of conscious decision in the individual's life. Brawer (1996), however, notes work during education as a factor leading to the dropout, as it puts a double burden on the students.

The attraction of the labor market is one of the most important reasons for delayed graduation and dropout stated by the Hungarian analyses as well. In the life of university students, there is no predetermined predictable period when they enter the world of work, and the date of entering employment does not fit the date of graduation (Bocsi, 2013). According to Kun (2014), the flexibility regarding the ability to enter the labor market from tertiary education means that the income of employees without a higher educational qualification is sometimes higher than those with a qualification. In this sense, the attraction of the labor market is decisive.

As the student dropout rate is high in Hungary (Derényi, 2015; Pusztai \& Kozma, 2009), we can suspect that intensive student employment contributes to poorer academic achievement, delays in fulfilling degree requirements, and to dropout, as well. It is obvious that students are influenced by various motivational factors, such as financial reasons and investment in human capital (Becker, 1994), or enriching their curriculum vitae through work experience (Bocsi, Fényes, \& Markos, 2017; Riggert et al., 2006). Student employment depends on the intensity of work undertaken (working hours per week) and on the financial support of the family (Riggert et al., 2006; Roshchin \& Rudakov, 2017).

Several forms of employment can increase academic achievement or even reduce inequality (Pusztai, 2011; Perna, 2012). It is clear from employers' experience that the employment of students has a positive effect on knowledge, results, and employment itself (Hovdhaugen, 2015; Pascarella \& Terenzini, 2005). Perna (2012) states that students' employment has an identity forming role, and increases engagement in graduation. It strengthens the ability to autoregulate and also has a positive effect on labor market performance.

\section{Sport}

In the Hungarian literature, the investigation of the connection between sport and academic achievement is underrepresented. In this study, we explore what kind of role sport could have in academic achievement and failure, and related to the latter, in dropout.

The connections are not obvious regarding the relationship between sport and academic achievement (especially in secondary and tertiary education). Some researchers have highlighted the positive effect of sport (Castelli, Hillman, Buck, \& Erwin, 2007; Field, Diego, \& Sanders, 2001; Hartmann, 2008), while some have drawn attention to its negative impact (Maloney \& McCormick, 1993; Purdy, Eitzen, \& Hufnagel, 1982) and others have found no connection between the two variables (Fisher, Juszczak, \& Friedman, 1996; Melnick, Sabo, \& Vanfossen, 1992).

The results of our investigation among students at the University of Debrecen highlighted the outstanding achievement of elite and regularly active athletes. Excluding two dimensions, these students achieved the best performance and the complex index of the elite athletes clearly showed that these students can achieve outstanding academic achievement alongside regular competitive sports participation. They are persistent and future-oriented, have good organising skills, are able to work hard, and can deal both with study and sport. Leisure-time athletes are more likely to follow norms, to evaluate learning as the most important activity, and the intensity with which they prepare for lessons and exams is the highest of all students. It was also confirmed among disadvantaged students that sport mediates values, norms, and behavioral rules, and it develops the personality, which can help to compensate for disadvantages regarding academic achievement (Kovács, 2015).

Regarding student dropout, first, the dimension of competitive sport concentrating on performance-development is underlined, in which achieving the best possible result is the target (Borbély \& Müller, 2008). This sport-specific good result (i.e., reaching a nationally recognized level) is only achievable if academic work is done consciously. Training, which means several hours per week and also requires good 
performance in competitions, is really time-consuming, if it is done at a really high level (i.e. a national and/or international level) and it can mean running the risk of poor academic achievement and dropout (Bowen \& Levin, 2003; Eitle \& Eitle, 2002; Miller, Melnick, Barnes, Farrell, \& Sabo, 2007).

\section{Social, entertainment, and leisure-time activities}

The individual's leisure-time habits and preferred activities depend not only on subjective interests but are also the result of value preferences and tastes determined by sociocultural and socialization factors (Bourdieu, 1998, 2008). "Partying" is one of the defining leisure-time activities of student life, as is confirmed by several studies (Müller, 2009; Murányi, 2010).

Behaviors related to non-formal education are one of the central questions of the investigation of non-academic achievement. These can show the efficacy of both prescriptive and proscriptive norms. The latter includes the avoidance of health-damaging behaviors such as illegal substance use (Pusztai, 2004) or smoking and alcohol consumption (Kovács, Nagy, \& Hegedüs, in press; Pusztai, Kovács, Kovács, \& Nagy, 2018). According to these results, avoiding risk factors, such as smoking, alcohol consumption, substance use, unsafe sexual behavior and suicide, and the lower prevalence of depressive symptoms, are indices of non-academic achievement. Several researchers emphasize that social leisure-time activities related to a student lifestyle, and belonging to a student community are outstanding predictors of health-risk behaviors.

In our previous student investigation, we reported on the effects of social party going and sporting leisure-time activity on the principal component of health-risk behavior: the more likely these activities are for the student, the more frequent is substance use, independent of individual, sociocultural, and demographical factors (Kovács, 2018). Thus, it is clear that leisure-time activities related to parties are risk factors regarding health-damaging behaviors, and that furthermore, the avoidance of these activities can be regarded as non-academic achievement factors. Besides this, excessive alcohol consumption and regular intoxication increase the risk of dropout and strengthen relationships with normbreaking peer groups, according to an investigation among Norwegian high-school students (Wichstrøm, 1998). According to the analysis, partying is a distraction or a maladaptive coping strategy when a student follows the wrong path: because of their unsuccessful courses and subjects, students become more desperate and disillusioned, they evaluate learning as less important and they seek a distraction such as partying or a paid job, which can distract them from failures related to learning (Daley, 2010). Thus, partying can be one of the most important factors in delayed graduation and in dropout.

\section{RESEARCH QUESTIONS AND METHODOLOGY}

Therefore, our research questions are that who dropped out of teacher education and why? What are the factors sociocultural background, family, friends, school career, employment while studying, and leisure-time activities (sports and entertainment) - that can predict institutional dropout?

The material was processed mainly alongside the codes assigned by the different topics of the interview. This paper does not cover all topics. The narrated life stories meant the basis of the analysis of the interviews where the stories told by the interviewees were regarded as the reality (Bordás, 2010; Conelly \& Clandinin, 2006; Kovács \& Vajda, 2002). The typed texts were interpreted as a surface (following the hermeneutics of Ricoeur and Gadamer) that can show us the individuals' experiences related to dropout. Therefore, the texts provided the relationship between the "reality" revealed by the interviewees and analysts (quotes Bordás, 2010). The typed interviews were divided into shorter units and the topics of the units were labeled on the basis of a primer code system corresponding to the weights of the research. Then, the units whose codes fit into the conceptual network of dropout were excluded from the interviews. During the categorization of these interview slices, the relationships between the codes, the hierarchical relationships, and the logical structure were labeled as well. Within this, the codes became more detailed, and furthermore, they were completed with other relevant emic codes that appeared during the analysis. Finally, a written form was created alongside the interview topics labeled with main and subcodes (Bordás, 2010; Conelly \& Clandinin, 2006; Kovács \& Vajda, 2002; Nagy, 2006; Tóth, 2004). The sampling is not random; therefore, our results cannot be generalized to the students of the investigated university. However, the findings of our research can help to reveal this less measured and difficulty tangible problem from a bottom-up perspective and to prepare a targeted research.

\section{EMPIRICAL STUDY}

\section{The sociocultural background}

The family backgrounds of the participants differ. Approximately half of the interviewees have parents with a low educational level who had at least a vocational education. In one quarter of the participants' families, there is at least one high-school graduate or technician and also in one quarter of the participants' families, there is at least one parent with a higher educational certificate. Three students mentioned divorce, mainly occurring during their high-school years. All of them describe a learning-supportive family atmosphere. However, support occurred for different reasons that were based on rational and less conscious decisions (Boudon, 1998; Pusztai, 2015a; learning without a concrete aim, earning more money, achieving more in one's lifetime, getting a degree is an obvious goal in the family) and was offered in different ways (verbal and financial support).

During high school, the impact of parents on learning becomes less marked. Some interviewees mentioned the less exaggerated expectations as positive points. These are contrary to performance pressure, which was experienced in all but one case. Freedom in decision-making and being treated as an adult even during secondary education are also positive points. However, several participants mentioned failure in the choice of course at secondary and tertiary 
levels. However, dropout caused by choices made by parents was mentioned, as well.

According to the results, students from different social layers highlighted the importance of different factors. The lower the social layer the student comes from, the higher the chance that employment during a course is a necessity and not a choice. But the family is important not only in terms of financial security: the values, norms, and coping strategies of the family are significant, as well. The more advantageous background the individual has, the greater the chances there will be an option outside the educational system in case of failure (Alivernini \& Lucidi, 2011; De Witte et al., 2013; Jimerson et al., 2000; Parr \& Bonitz, 2015).

Family background has a direct and indirect role in dropout. The direct effect includes everything that comes through norms and values. Regarding the participants, higher educational studies were parallel to moving away from parents (except for one or two participants), which leads to financial autonomy, or for a need for this autonomy. One participant said that he/she did not accept any support from his/her parents. In this separation process, the boundaries are blurred regarding the expansion of the parents' support. The anticipation of approaching studies (including some kind of theoretical and financial support), treating the departing child as an adult, providing her/him the choice to make decisions and transferring the parents' values and norms all occur imperceptibly and simultaneously.

Young adults are caught in the crossfire of expectations of which only one is achievable, that is, graduation from tertiary education. Moreover, the value of employment is also clear alongside these factors among parents with primary and secondary levels of educational. Parents themselves had already worked at this age, and the financial insecurity caused by studying can endanger the family and therefore employment becomes a necessity and not a choice. Among children of parents with a higher education qualification, employment while studying is generally a choice. Regarding the free choice aspect of students' decisions, selfpreservation, and gaining new knowledge and skills, and forming new relationships can be observed. Some say that this can be an escape from the oppressive atmosphere of higher education, and if they feel better in the workplace, they will quit education. This approach is in accordance with the theory of Bennett (2003), which draws attention to the pull-out effects of the labor market, while a job with good salary and flexible work schedules can be attractive against of the oppressive atmosphere of higher education. Starting a relationship and a family are frequently mentioned. The freedom of post-adolescence and partying can also reduce the importance of academic targets.

The risk of dropout increases exponentially if one of the factors mentioned becomes dominant over studying, and if the uncertainty caused by this is associated with doubts and problems in learning. This can occur, for example, if students do not have any confidence in the utility of their vocation, if they are disappointed in their teachers, the quality of the course, or its content. In the iceberg model, which is the basis for our research, this issue means the sixth dimension (school structures, resources, and practices). This includes all of the institutional and individual factors related to teaching and learning that support the student's academic career and strengthen their commitment to completing the studies. However, its lack may push the student toward dropping out.

The participants did not mention family members when referring to the moments, which led to dropout or in which the decision was made. These were their own decisions in which the family took part only after the decision was made and interpreted to them. These decisions were mainly accepted, although in a few cases the family was angry or disillusioned. Generally, the decisions were described as their own, or decisions which involved a friend or classmate, either in the decision itself or in coping with attendant difficulties; sometimes a student will follow the example of a friend or classmate who has quit.

On the whole, it seems that the family is not a direct actor in the process and does not take part in the decision-making. However, the effect of the family appears indirectly: financial insecurity, separating from parents, perceiving work as a value, a lack of connection between studies and the student's goals, a lack of the knowledge required to navigate the higher education system, etc.

\section{The years before higher education}

The colorful career paths among higher educational students can be seen to an increasing degree, which can be related not only to changing course, quitting or dropping out at the higher education level, but at the primary and secondary level, as well. These educational paths - which are not always linear - can be genuinely diverse.

It is obvious that the attitude of parents when supporting further education depends on their sociocultural environment and on their possibilities for supporting their children. The role of parents was decisive in everyday preparation and in completing homework. The role of grandparents was also visible in several multigenerational families. Individual support, encouragement, support in preparation, and support for private lessons and tuition were clear in the case of poorer families, as well. The academic achievement of the participants was good in primary school and several of them had outstanding results.

Regarding the choice of the institution at secondary level (grammar school, secondary school, and secondary vocational school), the student and the parent make a decision (together), which can lead to school-leaving certificate and further (higher) education, or a school-leaving certificate and a technician's certificate, or to a technician's certificate alone. Related to this, different learning outputs can be observed. First, several students showed improved academic achievement. On the other hand, failure and repetition could also be experienced, which can be an important indicator of the higher educational academic achievement and the dropout (Bánkúti et al., 2004; Liskó, 2003), or third, the same results could be achieved as was achieved in primary school.

The years of secondary education and the possibilities provided by the community obviously influence students in their academic achievement. Besides these factors, the activities conducted to assist career orientation and the supportive role of the school (especially supportive teachers) must be mentioned. According to the capabilities of the types of institution, student clubs, extracurricular 
activities, and private lessons were mentioned as reasons for the positive achievements of the participants.

The pressure of decision-making also predominated. In this, the supportive but expecting role of the family was significant, as well. According to the investigation of Csuka and Banász (2014), students' (individual) factors, such as their social and economic status, the parents' educational level, higher educational costs and scholarships, and the career advice given by close relatives (e.g., parents) all have a significant effect. We can see from interviews several students chose the same course as their parents had completed, or the one which conformed to family expectations. Family patterns (e.g., the plans of the parents and their extent) played a significant role in this pressure.

Regarding the factors causing failure, a connection could be experienced between the type of the secondary school and the courses selected. In the case of a higher educational course, which was different from the one selected in secondary school, the difficulties and bottlenecks were clearly visible from the beginning. Several participants reported that even in the first weeks, they did not receive an appropriate professional basis for the courses, which were necessary for their choice of profession. This is an important element in terms of the problems related to the period preceding higher education. This result draws attention to the responsibility of the secondary schools for the students' vocational guidance. It is important to provide more and more opportunity for the students to meet the various faculties as early as possible that includes not only labor market utilization and the social expectations, but also the skills and knowledge required to complete the training, and requirements of the profession.

It is clear that the educational career preceding higher education has a serious effect on higher educational dropout or on delayed graduation, and can be experienced through the role of the choice of institution in secondary education, the career orientation, the supportive role of the school, academic failures/successes, and the pressure on decisionmaking, too.

\section{The motivation of the choice of higher educational institution}

The majority of the participants made their decision at their secondary school during the last school year. The selection of the institution was not influenced by friends or acquaintances, and neither was the opinion of teachers significant. It can be stated that career decisions and institution selection must be separated. It is clear in several cases that institution selection is much more stable and occurs earlier than course selection. This can be explained by the importance of the location and the closeness of the institution. Measuring what motivates institution selection, the hierarchy of the selected institutions, and the place of the institution must also be taken into consideration. The majority of students could not list the ranking of the selected institutions and courses, because they made their choice before consulting these lists. The one student from abroad highlighted the fact the course was in the native language as the key component.

Regarding the choice of institution, another important statement is that students are highly influenced by their financial status. The participants explained the selection of the institution by the fact that they did not have to pay tuition fees, or they received a scholarship. Regarding another aspect of financial resources, it was also influenced by the possible opportunity to earn money in the future. Our results confirm the rational choice theory of Boudon. One of the key points of the theory is the cost-benefit analysis in which individuals or families assess the expected benefits of the university training/certification (the higher salary due to the degree in our case) while trying to minimize the costs of the graduation. One possible way can be to choose an institution close to the own settlement and, of course, to choose a state-funded training even if it is not the in the first place of the application list (Boudon, 1998; Pusztai, 2015a).

\section{Employment}

Our investigation underlined that working while studying in a higher educational institution plays an important role, and has a huge effect on the length of time involved in studying or on dropout. Employment appeared in several forms in the life of the interviewees. Their biggest motivational factor was earning money, so they did not have to depend on their parents and could finance their costs easier.

One interviewee's decision to quit a minor course was reinforced by the existence of a permanent job, since by quitting the student could keep a stable job and could even move up the career ladder, and this was more important than graduating. Similarly, another participant said that he/she secured a full-time job after dropping out.

Their case is in relation with the research results of Bennett (2003) and Kun (2014) who draw attention to the fact that a stable, possibly flexible and (apparently) lucrative job may be more attractive for the student than the academic difficulties related to the graduation. As a solution for the problems concerning the compatibility of the two areas, they rather choose to complete their studies since their long-term goal has already been achieved, they are integrated into the labor market, and they earn income too.

In some cases, a return to education could be observed: this occurred when time was spent in the labor market after breaking off from a course or before enrolling on a new course. One of the interviewees did part-time jobs and continued to work in the labor market after his unsuccessful application, and then started to work at the fire department. Later, he enrolled on a course but work took on an important role in his life and he also worked before and after dropout. After dropping out, he enrolled on another course but did not finish it as he could not see a clear path from the course to the labor market.

The third group of interviewees were made up of former correspondence students who were able to have full-time jobs thanks to the system. In their case, the main motivational factors were first their livelihood, and second the financing of their education.

The narratives of the participants supported the hypothesis that employment while studying and the attraction of the labor market have significant influences on dropout. It is clear that the role of the job is dominant, which can lead to quitting higher education studies (Brawer, 1996). Those interviewees, who decided to enter employment, did so partly because it represented financial safety and partly 
because it meant that future employment could be secured. Students underevaluated their courses in a few cases.

\section{Sport}

In our qualitative study, achieving a good result in sports and taking part in the National Championship could be seen as a target. A handball player in the National League 1st division who dropped out said that his academic achievement decreased in tandem with improved achievement in sport. This can be reversed, however, when he played in the 2nd division and had only three training sessions per week there was time to study and become successful. He stated that the priority of a sports career and achievement were the main reasons for dropping out. His sports career was a barrier with regard to his educational career and he had had bad experiences with teachers who often treated him in a patronizing way. He hardly spoke about his academic career with his peers, concentrating instead on sports results and successes. As a result of the frequent and long training sessions and switching to another institution, his academic achievement became poorer, which strengthens research results that emphasize the negative effect of sport on academic achievement (Maloney \& McCormick, 1993; Purdy et al., 1982). However, he performed well in his school-leaving exam and he prepared a lot for it, as he knew that it could determine his future. At his first university, where he started his higher educational studies, his sports career played a less important role in his life and he said the following: "I could manage to achieve better results. It was partying which distracted my energy from learning."

Among the interviewees, several athletes earned regular discretional income. The time necessary for studying can be reduced not only by sport but also by the time spent on sport and work. Employment requires responsibility and commitment, involving, for example, earning money even at a young age and for non-elite (amateur) competitions. These three components, that is, study, work, and sport are not easy to combine; it can be done well if the individual has outstanding skills and persistence, together with time-management skills. Some of the participants are leisure-time athletes looking for experience, community activities, and health promotion, as was also pointed out by Szabó (2006) and Pfau (2017). Among those who play at lower levels or only in their free time, sport is not a risk factor in dropout; moreover, it can support academic achievement and it also can be a protective factor against dropout, deviant behaviors, and those which present health risks (Kovács, 2015; Müller, 2009).

Sport as a leisure-time activity has a positive effect on learning and work as well; it supports socialization and competitiveness in the labor market (Hartmann, 2008). However, the support provided by competitive sport is not so obvious. Sport as a vocation requires so much time, responsibility, and commitment that it is more difficult to fulfill academic requirements. There should be no overemphasis on the negative effect of sport on dropout as it can also be influenced by other factors, including partying, employment, starting a family, a negligent attitude, laziness, or a lack of diligence, and all factors that act together as part of a wider context had a significant effect on delaying studies or on dropout.

\section{Social activities}

Parties play a dominant role in students' lives, and they frequently correlate with alcohol consumption and smoking. Campus life can be described as "buddies, parties, Fanta, girls, booze even three times per week." However, an exception can be also seen in the athlete who started to major in the sports department and had friends who regularly smoked and consumed alcohol, but who refrained from these activities, and was accepted by his friends, too. In this case, sport functions as a protective factor (Kovács, 2013, 2015; Mikulán, Keresztes, \& Pikó, 2010).

Partying by itself does not lead to dropout, but it can foster it in combination with other factors. It can be hypothesized that it causes problems in an academic career, if the student identifies campus life with partying and studying is increasingly neglected as the parties organized specially for university students can lead to a hedonistic and "carpe diem" lifestyle. However, we must mention other students who spent less time with parties and friends: "I worked and pursued sport besides studying, so friends and partying with them received less time in my life."

It is also clear that the majority of students traveled to home at weekends, as was reported by Murányi (2010). This was done for financial reasons. As a result of traveling, they spent less time in the institution; they knew each other less and had no common activities. They missed the close relationships between teachers and students.

The effect of social relationships and peers is indisputable regarding health-related behavior, sporting habits, and also learning motivation. Friends can be protective factors against delayed graduation and dropout if this group of friends and peers shows a positive attitude toward learning and vice versa. However, it also can have a negative impact on academic achievement if the peers' attitude is negative (Pusztai, 2011).

\section{SUMMARY}

In this study, we tried to uncover reasons for delayed graduation and dropout, which are difficult to observe by analyzing interviews. We interviewed people who had already dropped out or who had stayed in the educational system beyond the normally expected time.

The direct role of family members could not be highlighted in the process of delayed graduation or dropout; however, it is clear that it has an indirect impact through financial insecurity, assessing the value of work, the lack of the connection between learning and goals, a lack of information to navigate the higher education system, and the acceptance of alternatives outside the educational system.

The educational career prior to the higher educational years can also have a serious effect in several respects, including institution selection at secondary level, career orientation, the supportive role of the school, academic failures and successes, or the pressure on decision-making. The inappropriate selection of an institution or a course can significantly influence the student's path toward leaving without graduation. 
Working while studying can also contribute to poorer academic achievement, to delays in fulfilling requirements or to quitting the course without graduating. Beside this, competitive sport also does not support academic achievement, although leisure-time sport has a positive effect, both on learning and work efficiency. Furthermore, friendships also can protect against dropout, if the attitude of the group is positive toward learning.

But what can happen after dropout and quitting a course? Tinto (1975) has already drawn attention to the limitations of the research into the phenomenon of dropout, one of which was modeled scripts. We can add that it is not only these scripts but also paths after dropout that are lacking. At the same time, following up students who have dropped out is necessary, as the analyses, narratives, and subjective evaluation of the process at an individual level could be an important element in further studies.

When investigating life after dropout, we could not omit the development of youth-sociological frameworks for the relevant life period. Relevant theories relate to the beginning of adulthood and the quarter-life crisis, the fluid status of career socialisation, the destandardization of career paths or the phenomenon of NEET (Not in Employment, Education or Training; Kohli, 1990; Sánta, 2017; Vida, 2011). It is important to see that the life period following dropout is a fluid and path-finding period for young people that can be made even more unpredictable by quitting other institutions.

The first relevant statement to make may be the fact that dropout is predominately not a single and pointed change in the stakeholder's life, and this is reinforced by the fact that we can also observe a return to other institutions. Thus, dropout and the employment periods following it usually overlap, and there is often a shifting variety of attempts made to return to education.

We were also able to observe several attempts to return to higher education in our research sample. Another phenomenon can be observed in cases where dropout from a Master's course (MA/MSc) was caused by the student's stable position in the labor market. This temporary period, or periods, can be described as employment periods that fit destandardized life paths. These usually lead to employment in different sectors, and to working abroad in several cases. The initial employment is often the continuation of the student job that started during the higher educational studies and sometimes the workplace is the same and it is only the form of employment which differs (switching from a student job to a full-time job). More serious career moves could only be experienced by a few participants.

The experiences of the labor market also shape the expectations related to higher education. They can affect the relationship with the selection of the course, opinions regarding the value of the degree and the evaluation of the previous course. A mistaken or ill-considered career choice has a key role in the dropout phenomenon. In the years after dropout, the decision can be corrected. A higher level of interconnection between study plans and employment will be likely, which is mostly harmonized with the expectations of the family.

In harmony with the literature, in this study, it was not only individual evaluation but the effects of social status and the social environment, which also played an important role. Becoming passive or quitting the course is a conscious decision on the one hand, and an exigent response, on the other. Despite these considerations, the interviewees do not evaluate dropout as a mistake, but neither do they assess it as a positive experience.

The results of the qualitative analysis also indicate that dropout is not a definitive abandonment of higher educational plans. In the period after dropout, the expectation of graduating at some point in the future can be reinforced. This desire can be combined with a career correction too, and several participants planned to get their degree in another department or faculty (or have done so). The phenomenon of definitive dropout is rather a script (which is likely at the Master's level), but further follow-up studies are necessary to measure the extent to which learning plans are realized.

Funding sources: The study was supported by the János Bolyai Scholarship.

Authors' contribution: Each author contributed $10 \%$ for this study.

Conflict of interest: The author declares no conflict of interest.

\section{REFERENCES}

Alivernini, F., \& Lucidi, F. (2011). Relationship between social context, self-efficacy, motivation, academic achievement, and intention to drop out of high school: A longitudinal study. The Journal of Educational Research, 104(4), 241-252. doi:10.1080/00220671003728062

Astin, A. (1993). What matters in college? Four critical years revisited. San Francisco, CA: Jossey-Bass.

Bánkúti, Z., Horváth, Z., \& Lukács, J. (2004). A szakképzö iskolába járó diákok tanulási nehézségei [The learning difficulties of students learning in vocational schools]. Iskolakultúra, 14(5), 3-26. Retrieved from http://real.mtak.hu/60422/1/ EPA00011_iskolakultura_2004_05_003-026.pdf

Becker, G. S. (1975). Human capital: A theoretical and empirical analysis, with special reference to education (2nd ed.). New York, NY: National Bureau Economic Research.

Becker, G. S. (1994). Human capital revisited. In G. S. Becker (Ed.), A theoretical and empirical analysis with special reference to education (pp. 15-28). Chicago, IL: The University of Chicago Press.

Bennett, R. (2003). Determinants of undergraduate student dropout rates in a University Business Studies Department. Journal of Further and Higher Education, 27(2), 123-141. doi:10.1080/ 030987703200065154

Bocsi, V. (2013). Munkaértékek a felsőoktatásban [Working values in higher education]. In T. Darvai (Ed.), Felsőoktatás és munkaeröpiac-eszményektöl a kompetenciák felé [Higher education and labour market-from ideals to competencies] (pp. 67-87). Szeged, Hungary: SETUP-Belvedere Meridionale. 
Bocsi, V., Fényes, H., \& Markos, V. (2017). Motives of volunteering and values of work among higher education students. Citizenship Social and Economics Education, 16(2), 117-131. doi:10.1177/2047173417717061

Borbély, A., \& Müller, A. (2008). A testi-lelki harmónia összefüggései és módszertana [The connection and methodology of physical-mental harmony]. In I. Koncz (Ed.), Valóság-Térkép-6. PEM tanulmányok [Reality-map 6. PEM studies]. Budapest, Hungary: Professzorok az Európai Magyarországért Egyesület.

Bordás, A. (2010). A kisebbségi egyetemek kutatása hermeneutikai megközelítésben. In T. Kozma \& G. Pataki (Eds.), Kisebbségi felsőoktatás a Bologna-folyamatban (pp. 199-2014). Debrecen, Hungary: CHERD-Hungary.

Boudon, R. (1998). Limitation of rational choice theory. American Journal of Sociology, 104(3), 817-828. doi:10.1086/210087

Bourdieu, P. (1998). Practical reason: On the theory of action. Stanford, CA: Stanford University Press.

Bourdieu, P. (2008). A társadalmi egyenlötlenségek újratermelödése [The reproduction of social inequality]. Budapest, Hungary: General Press.

Bowen, W. G., \& Lewin, S. A. (2003). Reclaiming the game. College sports and educational values. Princeton, NJ/Oxford, UK: Princeton University Press.

Brawer, F. B. (1996). Retention-attrition in the Nineties. ERIC digest. ERIC Clearing house for Community Colleges. Retrieved from https://files.eric.ed.gov/fulltext/ED393510.pdf. Last accessed on: October 26, 2018.

Braxton, J. M., Shaw-Sullivan, A. V., \& Johnson, R. M. (1997). Appraising Tinto's theory of college student departure. In J. C. Smart (Ed.), Higher education: A handbook of theory and research 12 (pp. 107-164). New York, NY: Agathon.

Cabrera, A. F., Nora, A., \& Castaneda, M. B. (1993). College persistence. Structural equations modeling test of an integrated model of student retention. The Journal of Higher Education, 64(2), 123-39. doi:10.2307/2960026

Castelli, D. M., Hillman, C. H., Buck, S. M., \& Erwin, H. E. (2007). Physical fitness and academic achievement in thirdand fifth-grade students. Journal of Sport \& Exercise Psychology, 29(2), 239-252. doi:10.1123/jsep.29.2.239

Conelly, F. M., \& Clandinin, D. J. (2006). Narrative inquiry. In J. L. Green, G. Camilli, \& P. B. Elmore (Eds.), Handbook of complementary methods in education research (pp. 477488). Washington, DC: American Educational Research Association.

Csuka, G., \& Banász, Z. (2014). Lehetőségek és döntések [Possibilities and decisions]. Educatio, 4, 616-631.

Daley, F. (2010). Why college students drop out and what we do about it. College Quarterly, 13(3). Retrieved from https://files. eric.ed.gov/fulltext/EJ930391.pdf. Last accessed on: March 23, 2018.

de Corrado, F., \& Trivellato, P. (1977). Drop-outs from Italian Universities: 1960-1975. Paedagogica Europaea, 12, 81-105. doi: $10.2307 / 1502347$

Derényi, A. (2015). Bizonyítékokra alapozott kormányzás és a kommunikáció képzés [Evidence-based governance and communication training]. Jelkép. Advance online publication. 1-21. doi:10.20520/Jel-Kep.2015.1.KLSZ.21

De Witte, K., Cabus, S., Thyssen, G., Groot, W., \& van den Brink, H. M. (2013). A critical review of the literature on school dropout. Educational Research Review, 10, 13-28. doi:10.1016/ j.edurev.2013.05.002

Edmonds, R. (1979). Effective schools for the urban poor. Educational Leadership, 37(1), 15-18. Retrieved from https://pdfs. semanticscholar.org/550b/740eb13c411d36d38f498293472cf 64fdcef.pdf

Eitle, T. M., \& Eitle, D. J. (2002). Race, cultural capital, and the educational effects of participation in sports. Sociology of Education, 75(2), 123-146. doi:10.2307/3090288

Eurostat. (2016). More and more persons aged 30 to 34 with tertiary educational attainment in the EU. Retrieved from http://ec.europa.eu/eurostat/documents/2995521/7242558/327042016-AP-EN.pdf/83c2d88c-9ba8-47d7-8caf-8d765585967a. Last accessed on: March 19, 2018.

Fehérvári, A. (2012). Tanulási utak a szakképzésben [Learning paths in vocational education]. Iskolakultúra, 7-8, 2-19. Retrieved from http://epa.oszk.hu/00000/00011/00167/pdf/ EPA00011_Iskolakultura_2012-7-8.pdf

Fenyves, V., Bácsné Bába, É., Szabóné Szőke, R., Kocsis, I., Juhász, C., Máté, E., \& Pusztai, G. (2017). Kísérlet a lemorzsolódás mértékének és okainak megragadására a Debreceni Egyetem Gazdaságtudományi Kar példáján [Experiment for the measurement of the amount and reasons of the dropout at the faculty of Faculty of Economics and Business at the University of Debrecen]. Neveléstudomány, 3, 5-14. doi:10.21549/NTNY.19.2017.3.1

Field, T., Diego, M., \& Sanders, C. E. (2001). Exercise is positively related to adolescents' relationships and academics. Adolescence, 36, 105-110.

Fisher, M., Juszczak, L., \& Friedman, S. B. (1996). Sports participation in an urban high school: Academic and psychologic correlates. Journal of Adolescence Health, 18(5), 329-334. doi:10.1016/1054-139X(95)00067-3

Fulton, O. (1977). Drop-outs in Great Britain. Paedagogica Europeae, 12(3), 13-30. doi:10.2307/1502344

Galotti, K. M., \& Mark, M. C. (1994). How do high school students structure an important life decision? A short-term longitudinal study of the college decision-making process. Research in Higher Education, 35(5), 589-607. doi:10.1007/ BF02497089

Gyökös, E. (2015). Az iskolák teljesítményének nyomában. Az eredményességtől a hozzáadott értékig [Behind school performance. From success to added value]. In S. Mariann (Ed.), Eredményesség az oktatásban. Dimenziók és megközelitések [Success in education. Dimensions and approaches] (pp. 1122). Budapest, Hungary: Hungarian Institute For Educational Research And Development.

Hartmann, D. (2008). High school sports participation and educational attainment: Recognizing, assessing, and utilizing the relationship. Report to the LA84 Foundation. Retrieved from http://www.la84foundation.org/9arr/ResearchReports/ HighSchoolSportsParticipation.pdf

Hovdhaugen, E. (2015). Working while studying: The impact of term-time employment on dropout rates. Journal of Education and Work, 28(6), 631-65. doi:10.1080/13639080.2013.869311

Jimerson, S., Egeland, B., Sroufe, L. A., \& Carlson, B. (2000). A prospective longitudinal study of high school dropouts examining multiple predictors across development. Journal of School Psychology, 38(6), 525-549. doi:10.1016/S0022-4405 (00)00051-0 
Knafo, A., \& Sagiv, L. (2004). Values and work environment: Mapping 32 occupations. European Journal of Psychology of Education, 19(3), 255-273. doi:10.1007/BF03173223

Kohli, M. (1990). Társadalmi idő és egyéni idő [Social time and individual time]. In L. M. Gellériné (Ed.), Időben élnitörténeti-szociológiai tanulmányok [Living in time Historical-sociological studies] (pp. 175-212). Budapest, Hungary: Akadémiai Kiadó.

Kovács, É., \& Vajda, J. (2002). Elbeszélés, identitás és értelmezés. In É. Kovács, \& J. Vajda (Eds.), Mutatkozás (pp. 17-33). Budapest, Hungary: Múlt és Jövő Könyvkiadó.

Kovács, K. (2013). A sportoló közösségekhez tartozás mint társadalmi védőfaktor [Belonging to a sport community as a social protective factor]. Educatio, 2, 264-270.

Kovács, K. (2015). A sportolás mint támogató faktor a felsőoktatásban [Sport activity as a supportive factor in Higher education]. Debrecen, Hungary: CHERD-H.

Kovács, K. (2018). A comparison of factors influencing health risk behaviour of college students in the countries of the Carpathian basin. European Journal of Mental Health, 13(2), 184-210. doi:10.5708/EJMH.13.2018.2.5

Kovács, K., Kovács, K. E., \& Nagy, B. E. (2016). Institutional effects in students' health conscious behaviour. In A. Gál, J. Kosiewicz, \& T. Sterbenz (Eds.), Sport and social sciences with reflection on practice (pp. 13-30). Warsaw, Poland: Jozef Pilsudski University of Physical Education.

Kovács, K., Müller, A., Fenyves, V., Szücs, E., \& Bácsné, B. É. (2017). Miért éppen pedagógusképzés? Szakközépiskolások pedagógusképzésre irányuló tanulmányi motivációi a Kárpátmedencében [Why the educator training? The learning motivation of vocational school students for education training in the Carpathian Basin]. Neveléstudomány, 3, 15-30. doi:10. 21549/NTNY.19.2017.3.2

Kovács, K. E., Nagy, B. E., \& Hegedüs, R. (in press). The connection between health behaviour and academic achievement among Hungarian adolescents in an international comparison. Review of Applied Psychology/Revue Européenne de Psychologie Appliquée.

Kun, A. I. (2014). The sheepskin effect in the Hungarian labour market 2010-2012: Analysis of data from the Hungarian graduate tracking system. Annals of the University of Oradea Economic Science, 23(1), 492-499. Retrieved from http:// anale.steconomiceuoradea.ro/volume/2014/n1/051.pdf

Liskó, I. (2003). Kudarcok a középfokú iskolában [Failures in the secondary school]. Budapest, Hungary: Oktatáskutató Intézet.

Lukács, F., \& Sebő, T. (2015). Az egyetemi lemorzsolódás kérdőíves vizsgálata [The survey of higher educational dropout]. Iskolakultúra, 25(10), 78-86. doi:10.17543/ISKKULT.2015. 10.78

Maloney, M. T., \& McCormick, R. E. (1993). An examination of the role that intercollegiate athletic participation plays in academic achievement: Athletes' feats in the classroom. The Journal of Human Resources, 28(3), 555-570. doi:10.2307/146160

Melnick, M. J., Sabo, D. F., \& Vanfossen, B. (1992). Educational effects of interscholastic athletic participation on AfricanAmerican and Hispanic youth. Adolescence, 27, 295-308.

Miller, K. E., Melnick, M. J., Barnes, G. M., Farrell, M. P., \& Sabo, D. (2007). Untangling the links among athletic involvement, gender, race, and adolescent academic outcomes. Social Sport Journal, 2, 178-193. doi:10.1123/ssj.22.2.178
Mikulán, R., Keresztes, N., \& Pikó, B. (2010). A sport mint védőfaktor: fizikai aktivitás, egészség, káros szenvedélyek [Sport as a protective factor: Physical activity, health, addictions]. In B. Pikó (Ed.), Védőfaktorok nyomában. A káros szenvedélyek megelözése és egészségfejlesztés serdülőkorban [Behing protective factors. The prevention of health-damaging behaviours and health development in childhood] (pp. 115130). Budapest, Hungary: L'Harmattan-Nemzeti Drogmegelőzési Intézet.

Müller, A. (2009). A szabadidös tevékenységek kínálati elemeinek vizsgálata az egészségtudatos magatartás kialakitásában [The investigation of leisure-time activity possibilities in the development of health-conscious behaviour]. Debrecen, Hungary: Debreceni Egyetem ATC AVK.

Murányi, I. (2010). Egyetemisták szabadidős tevékenysége és mentális státusza [The leisure-time activity and mental status of university students]. Educatio, 2, 203-213.

Nagy, M. (2006). A tanárok "hangja". In J. Lannert, \& M. Nagy (Eds.), Az eredményes iskola. Adatok és esetek. Budapest, Hungary: Országos Közoktatási Intézet.

OECD. (2012). Equity and quality in education: Supporting disadvantaged students and schools. Retrieved from http:// dx.doi.org/10.1787/9789264130852. Last accessed on: March $15,2018$.

OECD. (2015). Education at a glance 2015-Hungary. Retrieved from https://www.oecd.org/hungary/Education-at-a-glance2015-Hungary-in-Hungarian.pdf. Last accessed on: December 28, 2016.

Parr, A. K., \& Bonitz, V. S. (2015). Role of family background, student behaviors, and school-related beliefs in predicting high school dropout. The Journal of Educational Research, 108(6), 504-514. doi:10.1080/00220671.2014.917256

Pascarella, E. T., \& Terenzini, P. T. (2005). How college. Affects students: A third decade of research. San Francisco, CA: John Wiley \& Sons.

Perna, L. W. (2012). Understanding the working college student new research and its implications for policy and practice. Sterling, VA: Stylus Publishers.

Pfau, C. S. (2017). A szabadidősport szervezési sajátosságai a felsőoktatásban [Organisational aspects of recreational sports at the tertiary level] (Doctoral thesis). Debrecen, Hungary: Debreceni Egyetem. Retrieved from https://dea.lib.unideb.hu/dea/ bitstream/handle/2437/236053/Pfau_Christa_Sara_ertekezes_ titkositott.pdf? sequence $=1 \&$ isAllowed $=y$. Last accessed on: March 26, 2018.

Purdy, D. A., Eitzen, S. D., \& Hufnagel, R. (1982). Are athletes also students? The educational attainment of college athletes. Social Problems, 29(4), 439-448. doi:10.2307/800032

Pusztai, G. (2004). Iskola és közösség: felekezeti középiskolások az ezredfordulón [School and community: Confessional secondary school students in the millennium]. Budapest, Hungary: Gondolat Kiadó.

Pusztai, G. (2011). A láthatatlan kéztől a baráti kezekig. A hallgatói értelmezö közösségek a felsőoktatásban [From the invisible hand to the gladhand. Students interpretive communities in higher education]. Budapest, Hungary: Új Mandátum.

Pusztai, G. (2015a). Pathways to success in higher education. Rethinking the social capital theory in the light of institutional diversity. Higher Education Research and Policy (HERP) 7. Frankfurt am Main, Germany: Peter Lang Edition. 
Pusztai, G. (2015b). Középiskolai hozzájárulás a hivatás formálódásához. Pedagógushallgatók és társaik összehasonlítása a kibocsátó középiskola fenntartója szerint [Secondary school added value to the development of vocation. The comparison of teacher students and their peers according to the authority of the secondary school]. In G. Pusztai, \& T. Ceglédi (Eds.), Szakmai szocializáció a felsőoktatásban. A pedagógusképzés kihívásai a Kárpát-medencébeng [Professional socialisation in higher education. The challenges of teacher education in the Carpathian Basin] (pp. 136-154). Nagyvárad, Romania/Budapest, Hungary: Partium-PPS-UMK.

Pusztai, G., Kovács, K. E., Kovács, K., \& Nagy, B. E. (2018). The effect of campus environment on students' health behaviour in four Central European countries. Journal of Social Research and Policy, 8(2), 1-14.

Pusztai, G., \& Kozma, T. (2009). Kié a doktori iskola? [Who owns the doctoral school?]. Educatio, 18(1), 64-75.

Riggert, S. C., Boyle, M., Petrosko, J. M., Ash, D., \& RudeParkins, C. (2006). Student employment and higher education: Empiricism and contradiction. Review of Educational Research, 76(1), 63-92. doi:10.3102/00346543076001063

Robinson, S., Jaggers, J., Rhodes, J., Blackmon, B. J., \& Church, W. (2017). Correlates of educational success: Predictors of school dropout and graduation for urban students in the Deep South. Children and Youth Services Review, 73, 37-46. doi:10.1016/j.childyouth.2016.11.031

Roshchin, S., \& Rudakov, V. (2017). Patterns of student employment in Russia. Journal of Education and Work, 30(3), 314-338. doi:10.1080/13639080.2015.1122182

Sánta, T. (2017). Analysis of registered NEETs' educational qualifications. In J. T. Karlowitz (Ed.), Differences in theory and practice (pp. 69-82). Komárno, Slovakia: International Research Institute sro.

Shahidul, S. M., \& Zehadul Karim, A. H. M. (2015). Factors contributing to school dropout among the girls: A review of literature. European Journal of Research and Reflection in Educational Sciences, 3(2), 25-36. Retrieved from https://www.idpublications.org/wp-content/uploads/2015/02/ FACTORS-CONTRIBUTING-TO-SCHOOL-DROPOUTAMONG-THE-GIRLS.pdf

Southerland, N. J. (2006). Formulating a new model of college choice and persistence. Retrieved from http://files.eric.ed.gov/ fulltext/ED493861.pdf. Last accessed on: March 12, 2018.
Szabó, Á. (2006). Egyetemisták szabadidősport-(szolgáltatás) fogyasztásai [The recreational sport (service) consuming habits of university students]. Budapest, Hungary: Corvinus Egyetem. Retrieved from http://edok.lib.uni-corvinus.hu/114/1/ Szabo76.pdf. Last accessed on: March 26, 2018.

Szemerszki, M. (2015). A tanulói eredményesség dimenziói és háttértényezői [The dimensions and background factors of academic achievement]. In M. Szemerszki (Ed.), Eredményesség az oktatásban. Dimenziók és megközelitések [Success in education. Dimensions and approaches] (pp. 52-88). Budapest, Hungary: Hungarian Institute For Educational Research And Development.

Teichler, U. (1998). The transition from higher education to employment in Europe. Higher Education in Europe, 23(4), 535-558. doi:10.1080/0379772980230411

Tinto, V. (1975). Dropout from higher education. A theoretical synthesis of recent research. Review of Educational Research, 45(1), 89-125. doi:10.3102/00346543045001089

Tóth, K. D. (2004). Magyarországi és angliai kiemelkedett cigányok identitástípusainak összehasonlitó elemzése (PhD értekezés). Budapest, Hungary: Közgazdasági Szemle Alapítvány.

UNESCO. (2012). World atlas of gender equality of education. Paris, France: UNECO.

Varga, J. (1998). Oktatás-gazdaságtan [Educational economy]. Budapest, Hungary: Közgazdasági Szemle Alapítvány.

Varga, Z. (2015). Hallgatói lemorzsolódás a felsőoktatásban [Student dropout in higher education].

Veres, E. (2017). Felsőoktatás-kutatások az Oktatási Hivatalban [Higher educational researches in the Department of Education]. Felsőoktatási Elemzési Jelentések, 1(2), 1. Retrieved from https://www.felvi.hu/pub_bin/dload/felsooktatasimuhely/ Elemzesi_Jelentesek/FEJ_2017_2.pdf

Vida, K. (2011). Kezdődő felnőttkor és kapunyitási pánik [The commencing adulthood and quarter-life crisis]. In Z. Puskás-Vajda \& S. Lesznyai (Eds.), Ifjúságkutatás és tanácsadás. A pszichológiai tanácsadás kutatási alapjai. (FETA Könyvek 6) [Youth research and counselling. The investigational bases of psychological counselling. (FETA Books 6)] (pp. 9-28). Budapest, Hungary: Felsőoktatási Tanácsadás Egyesület.

Wichstrøm, L. (1998). Alcohol intoxication and school dropout. Drug and Alcohol Review, 17(4), 413-421. doi:10.1080/ 09595239800187251 